\title{
Influence of Physical Raking and Biological Process in the Mud-water Exchange Dynamics of $P$ in Fish Culture Ponds
}

\section{*JATINDRA N. BHAKTA; JAYANTA K. BISWAS; BANA B. JANA}

\author{
Aquaculture and Applied Limnology Research Unit, Department of Zoology
}

University of Kalyani, Kalyani-741 235, West Bengal, India

\begin{abstract}
Experiment was conducted in the laboratory using radioactive ${ }^{32} \mathrm{P}$ for ascertaining the dynamics and quantifying the exchangeable amount of $\mathrm{P}$ between sediment and water phase under the influence of physical raking and biological processes. Collected sediment $(100 \mathrm{~g})$ was dispensed in a glass beaker and treated with radioactive ${ }^{32} \mathrm{P}$ after reaction with $\mathrm{CaCO}_{3}$. Each beaker filled with $250 \mathrm{ml}$ tap water. Four different treatments: physical raking once (RO), repeated raking (RR), bacteria (Bacillus, $167 \mathrm{X}_{10^{2}} \mathrm{ml}^{-1}$ ) inoculum (BI) and bacteria inoculum (Bacillus, $167 \times 10^{2} \mathrm{ml}^{-1}$ ) plus repeated raking $(\mathrm{BI}+\mathrm{RR})$ were used in the study. Water samples were collected and tested for specific activity of radioactive ${ }^{32} \mathrm{P}$, concentration of orthophosphate and count of heterotrophic bacterial (HB) population. The ${ }^{32} \mathrm{P}$ value of $\mathrm{BI}+\mathrm{RR}$ treatment was $20,25,37$ and $56 \%$ higher than $\mathrm{BI}$, $\mathrm{RR}, \mathrm{RO}$ and control, respectively. Therefore, it can be concluded that synergistic effect of bacteria inoculum plus repeated raking $(\mathrm{BI}+\mathrm{RR})$ released maximum amount of phosphorus than the rest three treatments. Critical appraisal of data clearly revealed four states of dynamic of ${ }^{32} \mathrm{P}$ between sediment and overlaying water: initial rapid increase of ${ }^{32} \mathrm{P}$ level in water - rapid desorption period (RDP) from day 0 to 12 , slow increase of ${ }^{32} \mathrm{P}$ level of water - slow desorption period (SDP) from day $>12$ to 55 , the ${ }^{32} \mathrm{P}$ moves to sediment resulting in decrease ${ }^{32} \mathrm{P}$ level in water absorption period (AP) from day $>55$ to 90 and steady period (SP) from day $>90$ to 124 , when ${ }^{32} \mathrm{P}$ concentration of water and sediment supposed to be equal indicating no movement of ${ }^{32} \mathrm{P}$ occurred between the water and sediment phase.@JASEM
\end{abstract}

Phosphorus is critical element having a role in the production and dynamics of aquatic ecosystem. Sediment can act as sink of these nutrients in unfertilized fish culture ponds, but it acts as a source of these nutrients in fertilized ponds. The equilibrium concentration of a nutrient may be too low for optimal phytoplankton growth, or the equilibrium concentration of a heavy metal may be high enough to cause toxicity to aquatic animals. An equilibrium exists between the concentration of a substance in the bottom soil and its concentration in the water. If the concentration in the water increases, the soil adsorbs the substance until equilibrium is reestablished. Boyd (1995) concluded that more phosphate would be released from the sediment to the overlaying water if the equilibrium is disturbed between the sediment and water. Conversely, if the concentration in the water decreases the soil desorbs the substance until the aqueous concentration is again at equilibrium. It is known that bottom mud of eutrophic water acts as sink in phosphorus, whereas it acts as a source of $\mathrm{P}$ to the over laying water in oligotrophic system (Pomeroy et al., 1965; Boyd, 1982). In ponds, the soil involve inputs and losses of substances, movement of substances within pond water and soil, transfer of substances across the soil-water interface, and uptake or release of substances by the soil through ion exchange, dissolution and decomposition. According to Tchobanoglous and Schroeder (1987), adsorption is a three-step process whereby the dissolved substance (1) moved by mass movement of water (advection) to the soil surface, (2) diffuses to the layer of water next to soil particles, and (3) attaches to or is adsorbed by the soil surface. The adsorbed substance is readily desorbed when concentration of the surrounding solution decreases.

In recent years, radioisotope-tracing methods have been employed in the measurement of different production pathways in matured fish culture ponds (Pekar and Olah, 1998). Several complex ecological processes are investigated by this technique, both to study the pathways and to estimate the levels of exchangeable nutrients between media. Substances that enter the soil may be stored permanently, or they may be transformed to other substances by physical, chemical or biological means and lost from the pond ecosystem. Metabolic activities of microorganisms in pond soil are critical factors in pond dynamics. Microorganisms use molecular oxygen in oxidizing organic matter to carbon dioxide and ammonia and other mineral nutrients are released. The problem of accumulation of nutrients either due to consecutive application of fertilizers has been a major problem in aquaculture ponds. This causes production cost to be high due to unnecessary application of fertilizer, which may become a source of pollution later. Although several studies have been made to delineate the strategy to increase the mud water exchange of $P$ in fish ponds, the same has not been done by physical shearing (raking) and biological processes (bacterial decomposition). It is, therefore, important to ascertain the level of $\mathrm{P}$ released from sediment to overlying water. The present investigation is aimed at ascertaining the influence of physical raking and biological process in the mud-water exchange dynamics of $\mathrm{P}$ in fish culture ponds. 


\section{MATERIALS AND METHODS}

The study was performed in the laboratory of the Department of Nuclear Medicine, Indian Institute of Chemical Biology, Calcutta. The used radioactive ${ }^{32} \mathrm{P}$ $\left(\mathrm{H}_{3}{ }^{32} \mathrm{PO}_{4}\right.$ form) was collected from the Board of Radiation and Isotope Technology, Department of Atomic Energy, Hydrabad, Government of India.

Fifteen $500 \mathrm{ml}$ beakers were provided with $100 \mathrm{~g}$ nutrient rich sediment $\left(\mathrm{pH} 7.4\right.$, Total-P $0.781 \mathrm{mg} \mathrm{l}^{-1}$ and Organic-C 18\%) collected from a fish pond. 25 $\mathrm{ml}$ distilled water of ambient temperature $\left(30^{\circ} \mathrm{C}\right)$ was added to $2.5 \mathrm{~g} \mathrm{CaCO}_{3}$ (which was taken in excess amount required for completion of the reaction) in a container. Then the required amount $(9 \mu \mathrm{l})$ of radioactive ${ }^{32} \mathrm{P}$ compound with specific activity of 72 $\mathrm{m}$ Curie was poured into it. The mixture was added to the sediment surface of each beaker. It was allowed for one hour to complete the reaction producing insoluble $\mathrm{Ca}_{3}\left({ }^{32} \mathrm{PO}_{4}\right)_{2}$.

$$
\mathrm{H}_{3}{ }^{32} \mathrm{PO}_{4}+\mathrm{CaCO}_{3} \longrightarrow \mathrm{Ca}_{3}\left({ }^{32} \mathrm{PO}_{4}\right)_{2}+\mathrm{CO}_{2}+\mathrm{H}_{2} \mathrm{O}
$$

Each beaker was provided with $250 \mathrm{ml}$ tap water. Of the fifteen beakers three were used as control. Rest of the beakers used as: physical raking once (RO) which raked once at the beginning of the experiment, repeated raking (RR), bacteria (Bacillus, $167 \times 10^{2}$ $\mathrm{ml}^{-1}$ ) inoculum (BI) and bacteria inoculum (Bacillus, $167 \times 10^{2} \mathrm{ml}^{-1}$ ) plus repeated raking (BI + RR). Thus, there were altogether 15 beakers allotted to four treatments and one control in triplicate $(5 \times 3=15)$. All the beakers were kept in the dark in the laboratory $\left(30^{\circ} \mathrm{C}\right)$ to avoid light induced algal growth and their phosphate uptake. The loss of water due to sampling was compensated by adding the equal volume of same water. The experiment was terminated when the phosphate level of water remained stationary. The water samples were collected from each treatment at a fixed hour (12 hour) of the day at regular intervals. The specific activity of radioactive ${ }^{32} \mathrm{P}$ of the collected water samples were determined by liquid scintillation counter and orthophosphate was monitored according to standard protocols of APHA (1995). The population density of heterotrophic bacteria (HB) was counted following the method described by Rodina (1972) during the period of study.

Adsorption and desorption efficiency of sediment was estimated. Assuming the substance of water column as $\mathrm{S}$, then the substance absorption and desorption by the sediment was written as, $\mathrm{S}_{\mathrm{A}}$ and $\mathrm{S}_{\mathrm{D}}$, respectively. $\mathrm{C}$ is designated for substance concentration in water column, then initial and final concentration was represented as $\mathrm{C}_{\mathrm{i}}$ and $\mathrm{C}_{\mathrm{f}}$. T was depicted as time, then final and initial time represented as $\mathrm{T}_{\mathrm{f}}$ and $\mathrm{T}_{\mathrm{i}}$, respectively. The rate of adsorption and desorption of sediment can also be expressed in per cent as:

$$
\begin{aligned}
& S_{A}(\text { adsorption })=\frac{C_{i}-C_{f}}{T_{f}-T_{i}} \times 100 \\
& S_{D}(\text { Desorption })=\frac{C_{f}-C_{i}}{T_{f}-T_{i}} \times 100
\end{aligned}
$$

All results obtained from the study were statistically evaluated. A one way ANOVA (Gomez and Gomez, 1984) was used to compared the treatment means. If the main effect was found significant, the ANOVA was followed by a LSD (least significance difference) test. All statistical tests were performed at 5\% probability level using statistical package EASE and M-STAT.

\section{RESULTS AND DISCUSSION}

Radioactive ${ }^{32} \mathrm{P}$ : The $\mathrm{CPM}$ values of ${ }^{32} \mathrm{P}$ in water varied (CPM 16.43 - 50.54) significantly (ANOVA; $\mathrm{P}<0.05)$ in all the treatments employed. The mean value was maximum (CPM 36.26) in the treatment used bacterial inoculum plus repeated raking (BI + $\mathrm{RR})$ and exhibiting the following order of variations: $\mathrm{BI}+\mathrm{RR}>\mathrm{BI}>\mathrm{RR}>\mathrm{RO}>$ control $($ Table 1$)$. The ${ }^{32} \mathrm{P}$ value in $\mathrm{BI}+\mathrm{RR}$ was $20,25,37$ and $56 \%$ higher than in $\mathrm{BI}, \mathrm{RR}, \mathrm{RO}$ and control, respectively.

Orthophosphate $\left(\mathrm{PO}_{4}-\mathrm{P}\right)$ : The concentration of $\mathrm{PO}_{4}$ $\mathrm{P}$ of water ranged from $0.027-0.337 \mathrm{mgl}^{-1}$. There was a significant treatment difference (ANOVA; $\mathrm{P}<0.05$ ) in mean values of $\mathrm{PO}_{4}-\mathrm{P}$ showing the trend of variation as follows: $\mathrm{BI}+\mathrm{RR}>\mathrm{BI}>\mathrm{RR}>\mathrm{RO}>$ control. The highest mean value $\left(0.245 \mathrm{mg} \mathrm{l}^{-1}\right)$ was $1.21,1.4,2.13$ and 2.207 fold higher than BI, RR, RO and control, respectively (Table 1).

Heterotrophic Bacteria (HB): The counts of HB varied between 109 and $259 \times 10^{4} \mathrm{ml}^{-1}$ in different treatments. In $\mathrm{BI}+\mathrm{RR}$ treatment, the maximum number of HB $\left(259 \times 10^{4} \mathrm{ml}^{-1}\right)$ was $9,22,26$ and $49 \%$ higher than in $\mathrm{BI}, \mathrm{RR}, \mathrm{RO}$ and control, respectively (Table 1). Temporal changes in count of HB exhibited a slight declining trend till day 8 followed by gradual increasing trend up to day 55 and steady afterwards.

The relatively higher concentration of radioactive ${ }^{32} \mathrm{P}$ was found in the treatment where bacteria inoculum and repeated raking $(\mathrm{BI}+\mathrm{RR})$ were employed. Synergistic effect of bacteria inoculum and repeated raking $(\mathrm{BI}+\mathrm{RR})$ desorped 219, 140 and 50\% higher phosphorus over raking once, repeated raking and bacteria inoculum alone, respectively (Fig. 1). 


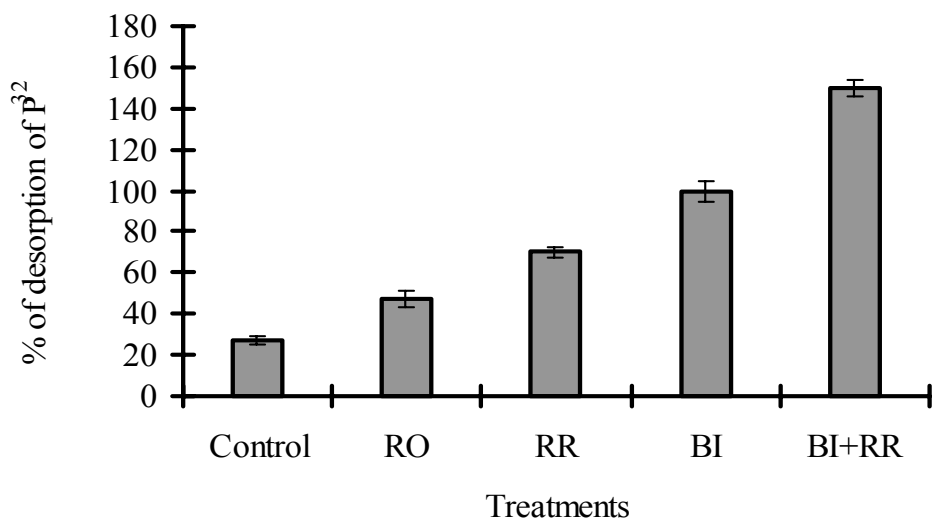

Fig. 1. Percent of desorption of ${ }^{32} \mathrm{P}$ by sediment in different treatments.

The bioturbation activity increases the nutrient release from the sediment (Jana et al., 1992; Jana and Das, 1992a,b; Jana and Sahu, 1993, 1994) and Chakraborty et al. (2004) concluded that raking accelerate the transformations of available-P from sediment to over laying water. According to Petr (1977), bioturbation increases the influx of water to the sediment, which much equal the volume of water containing solutes flushed from sediments.

Substantial increase in the orthophosphate concentration $(1248 \%)$ in bacteria inoculum and repeated raking $(\mathrm{BI}+\mathrm{RR})$ treatment was higher than raking once $(25 \%)$, repeated raking $(7 \%)$ and bacteria inoculum $(17 \%)$, which was clearly indicated that cumulative effect of bacterial inoculum and repeated raking create favourable conditions to break barrier for transforming the phosphate from sediment to overlaying water. The effect of raking mainly supposed to depend on the mixing of the sediment surface layer and the breakdown of the chemical barrier (Sahu and Jana, 1996; Chakraborty et al., 2004). In bacteria inoculum and repeated raking (BI + RR) treatment, highest bacterial population facilitates to release of maximum phosphorus than other treatments

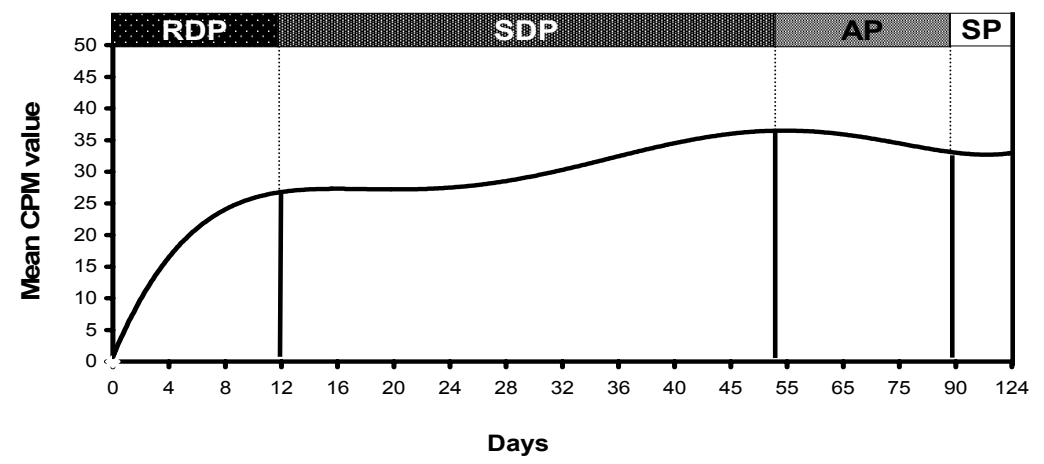

Fig. 2. Dynamics of Radioactive ${ }^{32} \mathrm{P}$ between water and sediment through exchange process with time scale.

Higher concentration of ${ }^{32} \mathrm{P}$ in sediment make an inequilibrium condition in respective nutrient between sediment and water phase which resulting in movement of ${ }^{32} \mathrm{P}$ from sediment to overlying water to reach a balance state. According to Boyd (1995) if the nutrient concentration in the water increases, the soil will adsorb the substance until equilibrium is reestablished, conversely, if the nutrient concentration in water decreases they will desorp the substance until the aqueous concentration is again at equilibrium 
Table 1. Mean values $( \pm$ S.E. $)$ of radioactive ${ }^{32} \mathrm{P}$, orthophosphate and heterotrophic bacterial population in water in different treatments. Same script among treatments (rows) revealed lack of significant difference.

\begin{tabular}{lccccc}
\hline Parameters & \multicolumn{5}{c}{ Treatments } \\
\cline { 2 - 6 } & Control & RO & RR & BI & BI+RR \\
Radioactive ${ }^{32} \mathrm{P}(\mathrm{CPM})$ & $23.2^{\mathrm{D}}$ & $26.4^{\mathrm{C}}$ & $29^{\mathrm{B}}$ & $30.06^{\mathrm{B}}$ & $36.26^{\mathrm{A}}$ \\
& \pm 0.7 & \pm 0.59 & \pm 0.57 & \pm 0.64 & \pm 0.7 \\
& & & & \\
Orthophosphate $\left(\mathrm{mg} \mathrm{l}^{-1}\right)$ & $0.111^{\mathrm{E}}$ & $0.155^{\mathrm{D}}$ & $0.176^{\mathrm{C}}$ & $0.202^{\mathrm{B}}$ & $0.246^{\mathrm{A}}$ \\
& \pm 0.01 & \pm 0.005 & \pm 0.015 & \pm 0.03 & \pm 0.03 \\
Heterotrophic bacteria & $138^{\mathrm{E}}$ & $163^{\mathrm{D}}$ & $170^{\mathrm{C}}$ & $190^{\mathrm{B}}$ & $207^{\mathrm{A}}$ \\
$\left(\mathrm{x} 10^{3} \mathrm{ml}^{-1}\right)$ & \pm 4 & \pm 6 & \pm 7 & \pm 6 & \pm 9 \\
\hline
\end{tabular}

Critical appraisal of data clearly revealed four states of dynamic of ${ }^{32} \mathrm{P}$ between sediment and overlaying water; initial rapid increase of ${ }^{32} \mathrm{P}$ level in water due to initial higher ${ }^{32} \mathrm{P}$ concentration in sediment - rapid desorption period (RDP) from day $0-12$, slow increase of ${ }^{32} \mathrm{P}$ level of water because of moderate concentration of sediment ${ }^{32} \mathrm{P}$ - slow desorption period (SDP) from day $>12-55$, because of slightly low concentration of ${ }^{32} \mathrm{P}$ in sediment than water the ${ }^{32} \mathrm{P}$ moves to sediment resulting in decreased ${ }^{32} \mathrm{P}$ level in water - absorption period (AP) from day $>55-90$ and steady period (SP) from day $>90-124$, when ${ }^{32} \mathrm{P}$ concentration of water and sediment supposed to be equal indicating no movement of ${ }^{32} \mathrm{P}$ occurred between the water and sediment phase (Fig. 2). Sedimentation, adsorption or precipitation, chemical transformation and phosphorus uptake are some of the mechanism for phosphorus dynamics in natural water (Williams and Mayer, 1972; Bostrom et al., 1988; Wetzel, 2001). It has been proposed that the upper few millimeters of the sediment exchange is controlled by motions of molecular scales with correspondingly low diffusion rates (Wetzel, 2001). Latterell et al. (1971) found that orthophosphate concentration in water must be extremely low before sediments will release phosphate.

Conclusion: It implies from the study that (1) the bacteria inoculum and repeated raking $(B I+R R)$ synergistically can be used as a management tool for releasing the maximum nutrient from sediment to overlaying water and (2) time scale dynamics of the $\mathrm{P}$ in the mud-water exchange process.

\section{REFERENCES}

APHA (1995). Standard Methods for the Examination of Water and Wastewater. $19^{\text {th }}$ edn, American Public Health Association, Washington, DC.

Austin, B (1990). Methods in Aquatic Bacteriology. John Wiley and Sons, New York.
Bostrom, B; Andersen, JM; Fleischer, S; Jansson, M (1988). Exchange of phosphorus across the sediment-waterinterface. Hydrobiologia 170: 229-224.

Boyd, CE (1982). Water quality management for pond fish culture. Elsevier Scientific Publishing Company, Amsterdam, Oxford, New York.

Boyd, CE (1995). Bottom Soils, Sediment, and Pond Aquaculture. Chapman and Hall, New York.

Chakraborty, P; Biswas, JK; Jana, BB (2004). Sediment raking as a tool for enhencement of phosphate and productivity of water in tropical pond system. Hydrobiologia 524: 157-165.

Gomez, KA; Gomez, AA (1984). Statistical Procedures for Agricultural Research. $2^{\text {nd }}$ edn. John Wiley and Sons, New York.

Jana, BB; Sahu, SN (1993). Relative performance of three bottom grazing fishes (Cyprinus carpio, Cirrhinus mrigala, Heteropneustes fossilis) in increasing the fertilizer value of phosphate rock. Aquaculture 115: 19-29.

Jana, BB; Sahu, SN (1994). Effect of frequency of rockphosphate application in carp culture. Aquaculture 122: 313-321.

Jana, BB; Das, SK (1992a). Bioturbation-induced changes of fertilizer value of phosphate rock in relation to alkaline phosphatase activity. Aquaculture 103: 321-330.

Jana, BB; Das, SK (1992b). The fertilizer value of phosphate rock in carp culture. Bamidgeh 44: 1323.

Jana, BB; Das, SK; Chakravorty, D (1992). Use of common carp (Cyprinus carpio L.) in increasing the fertilizer value of phosphate rock. Journal of Applied Ichthyology 8: 222-227. 
Latterell, JJ; Holt, RF; Timmons, DR (1971). Phosphate availability in lake sediments. J Soil and Water Cons 26: 21-24.

Pekar, F; Olah, J (1998). Fish pond manuring studies in Hungary. In: Mathias, JA; Charles, AT; Wuxi Baotong, H (Eds.) Proceedings of a Workshop on Integrated Fish Farming, Jiangsu Province, Peoples's Republic of China. CRC Press LLC, Integrated Fish Farming, pp 163-177.

Petr, T (1977). Bioturbation and exchange of chemicals in the mud water interface. In: Junk, BV; Golterman, HL (Eds.) Interactions between Sediments and Fresh water, The Hague, pp 216226.

Pomeroy, LR; Smith, BB; Grant, CM. (1965). The exchange of phosphate between estuarine water and sediment. Limnology and Oceanography 10: 167-172.

Rodina, AG (1972). Methods in Aquatic Microbiology. R.R. Colwell and M.S. Zambruski (Eds.), University Park Press. Baltimore, Butterworths, London.
Sahu, SN; Jana, BB (1996). Manipulation of stocking ratios between surface-and bottom-grazing fishes as a strategy to increases the fertilizer value of rockphosphate in a carp polyculture. Aquaculture Research 27: 931-936.

Schroeder, GL (1974). Use of fluid cowshed manure in fish ponds. Bamidgeh 26 (1): 84-96.

Shrestha, MK (1994). Dynamics and recovery of phosphorus in mud of fertilizer fish pond. D. Technical Dessertation no. AE-94-2, Asian Institute of Technology, Bangkok, Thiland.

Tchobanoglous, G; Schroeder, ED (1987). Water Quality. Addison-Wesley Publishing Company, Reading, MA.

Wetzel, RG (2001). Limnology: Lake and River Ecosystem. Academic Press, California.

Williams, JDH; Mayer, T (1972). Effects of sediment diagenesis and regenaration of phosphorus with special reference to lakes Eire and Ontario. In: Allen, HE; Kramer, JR (Eds.) Nutrients in Natural Waters, John Wiley \& Sons, New York, pp 281-315. 